\title{
12. Using Tellus data to enhance targeting of volcanogenic massive sulphide mineralisation in the Tyrone Igneous Complex
}

\author{
Steven Hollis, ${ }^{1}$ Mark Cooper, ${ }^{2}$ Garth Earls, ${ }^{3}$ Stephen \\ Roberts, ${ }^{4}$ Richard Herrington ${ }^{5}$ and Stephen Piercey ${ }^{6}$
}

How to cite this chapter:

Hollis, S.P., Cooper, M.R., Earls, G., Roberts, S., Herrington, R.J. and Piercey,

S.J., 2016 'Using Tellus data to enhance targeting

of volcanogenic massive sulphide mineralisation in the Tyrone Igneous Complex' in M.E. Young (ed.), Unearthed: impacts of the Tellus surveys of the north of Ireland. Dublin. Royal Irish Academy.

DOI:10.3318/ 978-1-908996-88-6.ch12
The Tyrone Igneous Complex of Northern Ireland has been a target for base and precious metal exploration since the 1970s. Historic exploration was hampered by poor exposure and consequently a limited understanding of the local geology. Extensive new field mapping, utilising the high-resolution Tellus geophysical survey, coupled with $\mathrm{U}-\mathrm{Pb}$ zircon geochronology and whole-rock geochemistry, has greatly improved our understanding of the complex and its potential to host volcanogenic massive sulphide (VMS) mineralisation. Targeting of Tellus and historic, geochemical and geophysical anomalies along VMS prospective stratigraphic horizons has identified new mineral occurrences and areas for further exploration. A correlation has been made with the Buchans-Robert's Arm arc system of Newfoundland, host to numerous economic deposits.

\section{INTRODUCTION}

VMS deposits are ancient accumulations of base and precious metal sulphides that formed at or under the seafloor (Fig. 12.1). Deposits formed through the precipitation of sulphides from metal-enriched, high-temperature hydrothermal fluids during mixing with seawater. Heat was derived from contemporaneous volcanism, with metals such as iron $(\mathrm{Fe})$, copper $(\mathrm{Cu})$, lead $(\mathrm{Pb})$ and zinc $(\mathrm{Zn})$ leached from underlying rocks (Galley et al., 2007). Modern analogues are well documented, and firmly established in the public

\footnotetext{
' iCRAG/University College Dublin.

${ }^{2}$ Geological Survey of Northern Ireland, Belfast.

${ }^{3}$ University College Cork.

${ }^{4}$ University of Southampton.

${ }^{5}$ Natural History Museum, London.

${ }^{6}$ Memorial University of Newfoundland, St John's, Canada.
} 


\section{Hollis et al.}

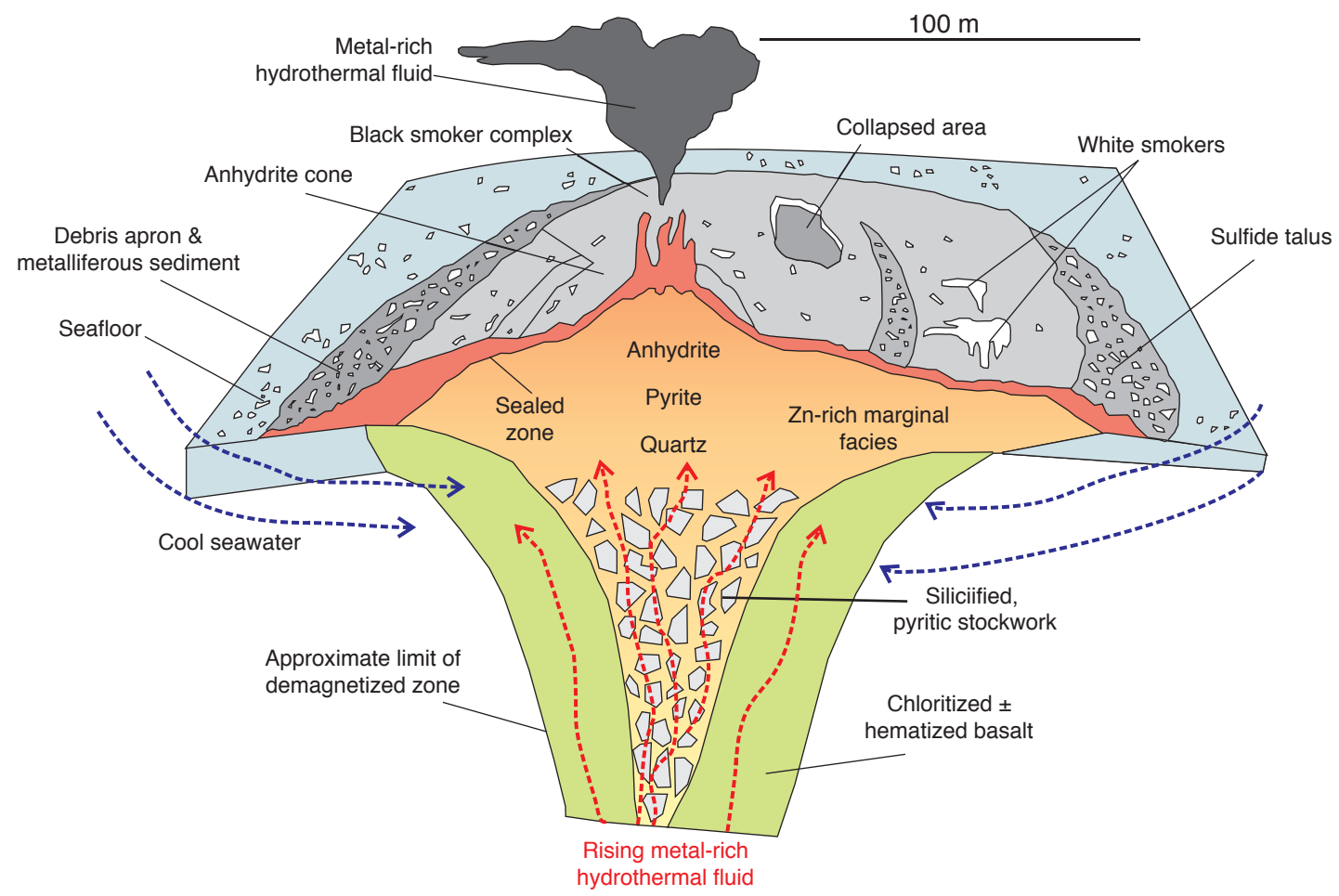

consciousness through media interest in black smoker systems teeming with life at water depths of -500 to $5000 \mathrm{~m}$.

The Ordovician Tyrone Igneous Complex of Northern Ireland (Fig. 12.2) covers -350 $\mathrm{km}^{2}$ within counties Tyrone and Londonderry, and includes the remnants of an island arc system and subduction-related ophiolite accreted to the continental margin of Laurentia at c.470 Ma (Cooper et al., 2011). This event represents an early phase of the closure of the Iapetus Ocean, which eventually resulted in the amalgamation of Great Britain and Ireland by c.420 Ma (the Caledonian orogeny). This mountain belt continues through North America (the Appalachians), where over 40 VMS deposits have been recognised in Newfoundland alone (Piercey, 2007). Although the Tyrone Igneous Complex has been a target for base and precious metal exploration since the 1970s, no occurrences of economic size have yet been identified. Mineral exploration across much of Ireland is hampered by poor exposure, due to extensive peat cover and thick glacial deposits. This contribution details how Tellus data were used for field mapping and the subsequent targeting of mineralisation.

\section{Methods}

Approximately six months of geological mapping was undertaken across the Tyrone Igneous Complex during the summers of 2009 and 2010 (Hollis, 2013), preceded by visual
Figure 12.1. Schematic diagram of the modern TAG volcanogenic massive sulphide deposit on the Mid-Atlantic Ridge, which represents a classic cross-section through a mafic-hosted VMS deposit (redrawn after Galley et al., 2007). 


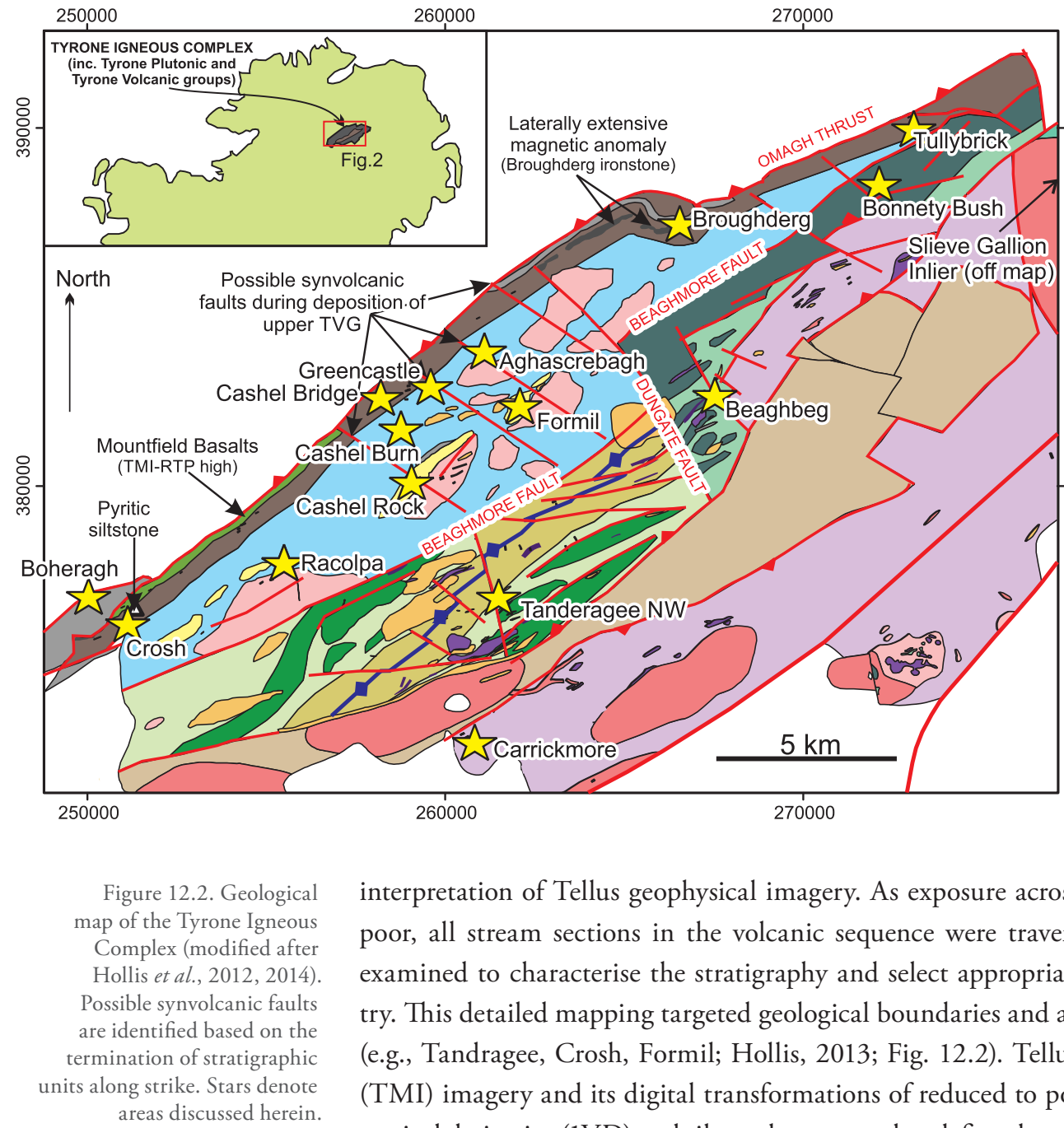

260000

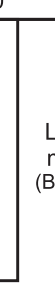

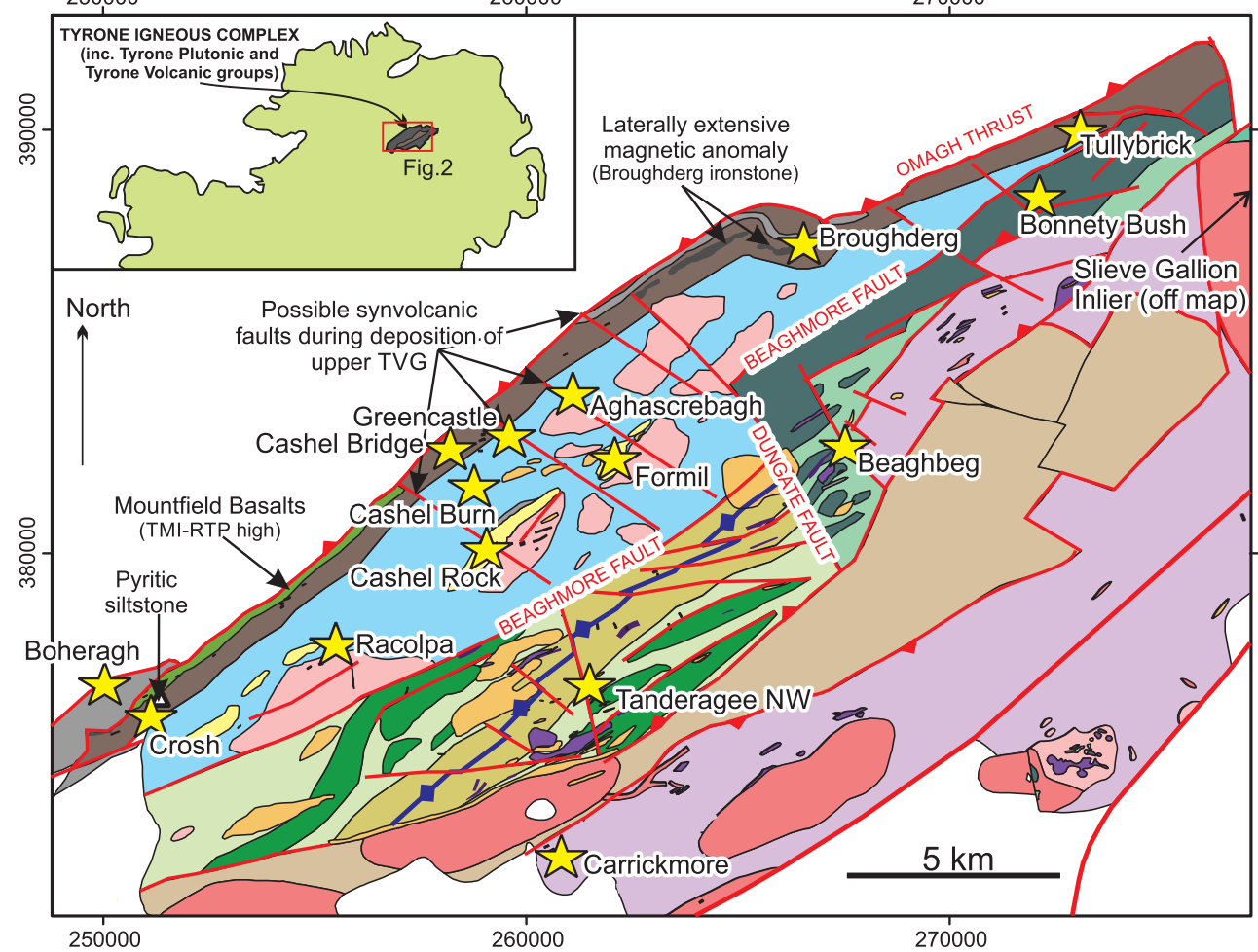

Laterally extensive
magnetic anomaly

(Broughderg ironstone)

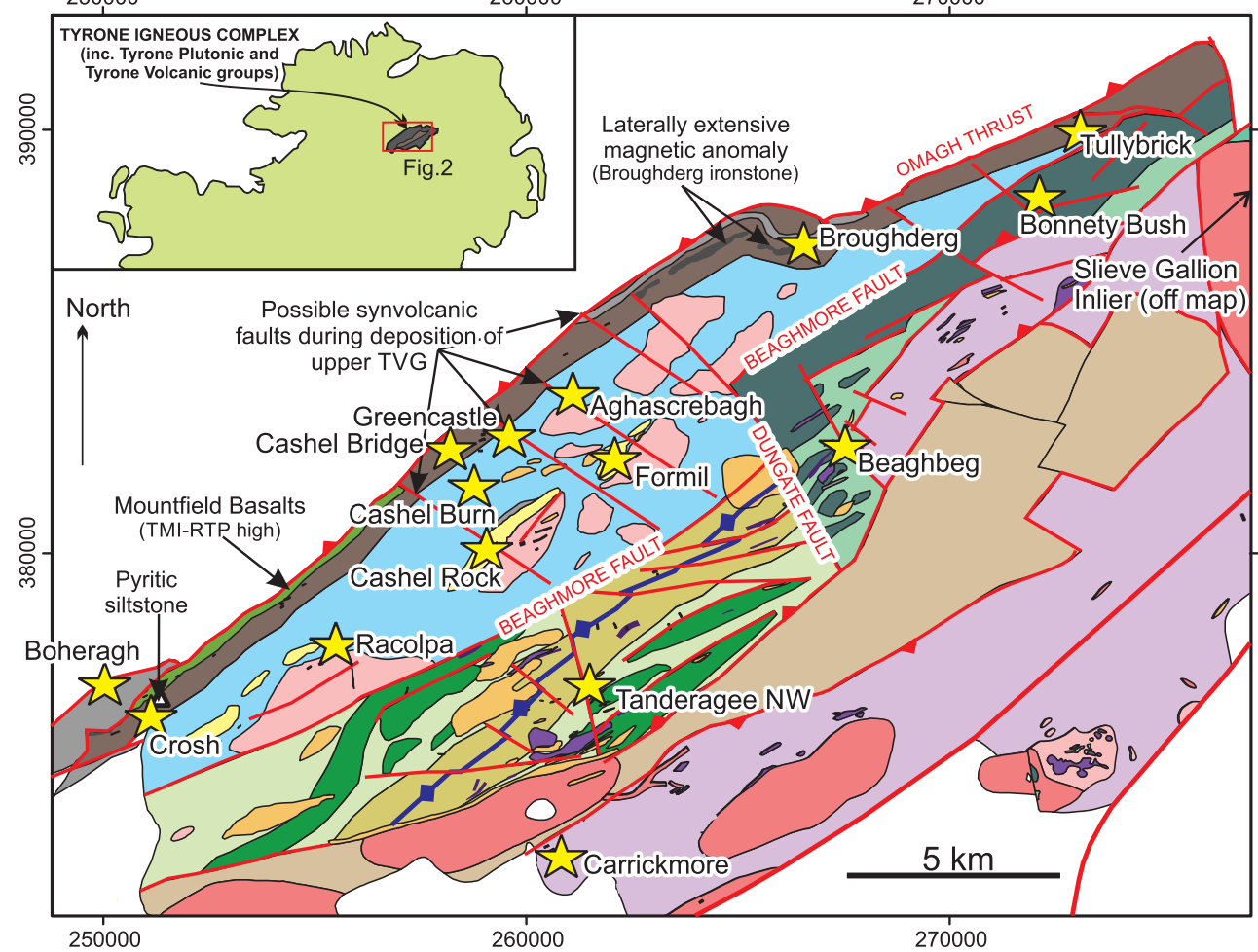

(Bronstone)

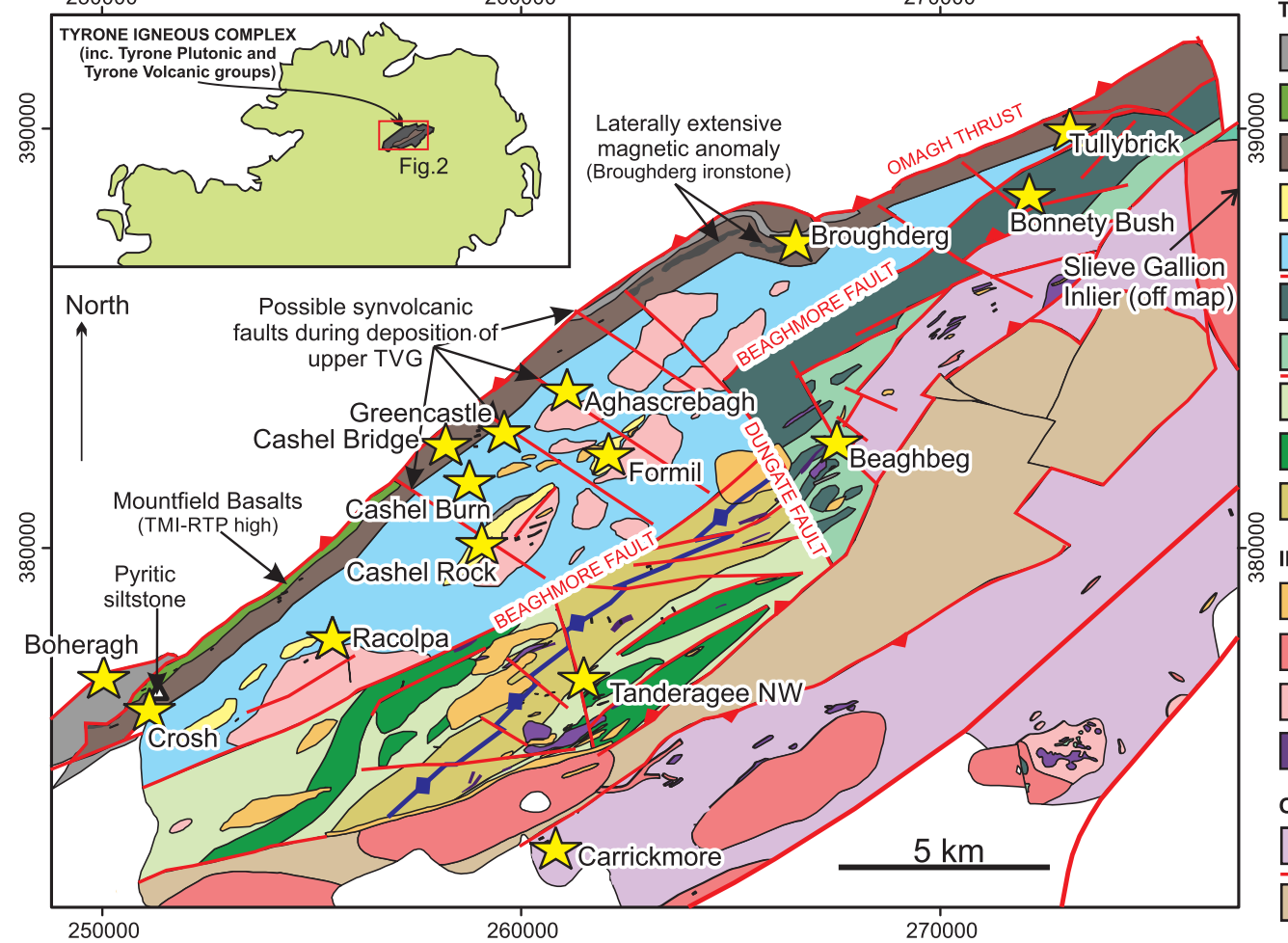

270000
TYRONE VOLCANIC GROUP (c. 475-469 Ma)

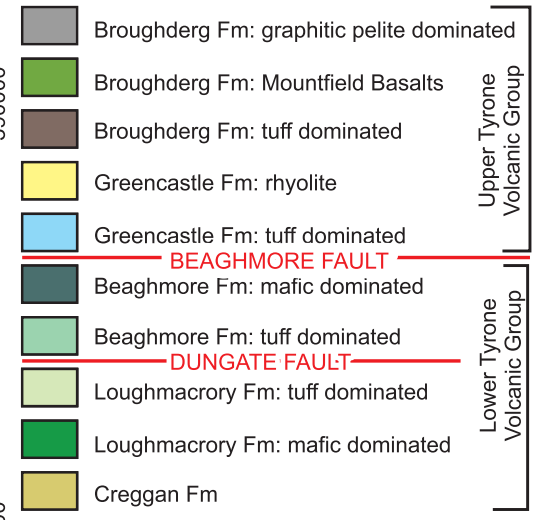

\section{INTRUSIVE ROCKS}

Quartz-porphyry (c. $464 \mathrm{Ma}$ )

Granite (c. 467-465 Ma)

Tonalite (c. 470-465 Ma)

Dolerite/diorite/gabbro (c. 475?-470 Ma) OTHER

$\square$ Tyrone Plutonic Group (c. 484-479 Ma)
$\square$ Tyrone Central Inlier (c. $600 \mathrm{Ma}$ ?)
Figure 12.2. Geological map of the Tyrone Igneous Complex (modified after Hollis et al., 2012, 2014). Possible synvolcanic faults are identified based on the termination of stratigraphic areas discussed herein. interpretation of Tellus geophysical imagery. As exposure across much of the complex is poor, all stream sections in the volcanic sequence were traversed and known outcrops examined to characterise the stratigraphy and select appropriate samples for geochemistry. This detailed mapping targeted geological boundaries and areas of increased exposure (e.g., Tandragee, Crosh, Formil; Hollis, 2013; Fig. 12.2). Tellus total magnetic intensity (TMI) imagery and its digital transformations of reduced to pole (RTP; Fig. 12.3a), first vertical derivative (1VD) and tilt-angle were used to define the extent of magnetite-bearing basalt, dolerite, gabbro and ironstone in the structurally lower levels of the complex. Electrical conductivity imagery highlighted the lateral extent of thick sequences of graphitic pelite around Broughderg and Boheragh in the uppermost part of the stratigraphy (Fig. 12.3b), confirmed through fieldwork, and subsequently in 2011 by drilling. Faults are clearly identified from the offset of magnetic units along strike (e.g. Slieve Gallion, Tandragee). Tellus geophysical data allowed isolated outcrops in the Tyrone Igneous Complex to be placed in a detailed structural and stratigraphic framework for the first time (Hollis et al., 2012, 2013a). This then provided the context for whole-rock geochemical analysis and high-resolution uranium-lead (U-Pb) zircon geochronology.

Approximately 450 samples from outcrop and historic drillcore were analysed for whole-rock geochemistry at the British Geological Survey and University of Southampton (described in Hollis et al., 2012). Sixteen samples from the Tyrone Igneous Complex 


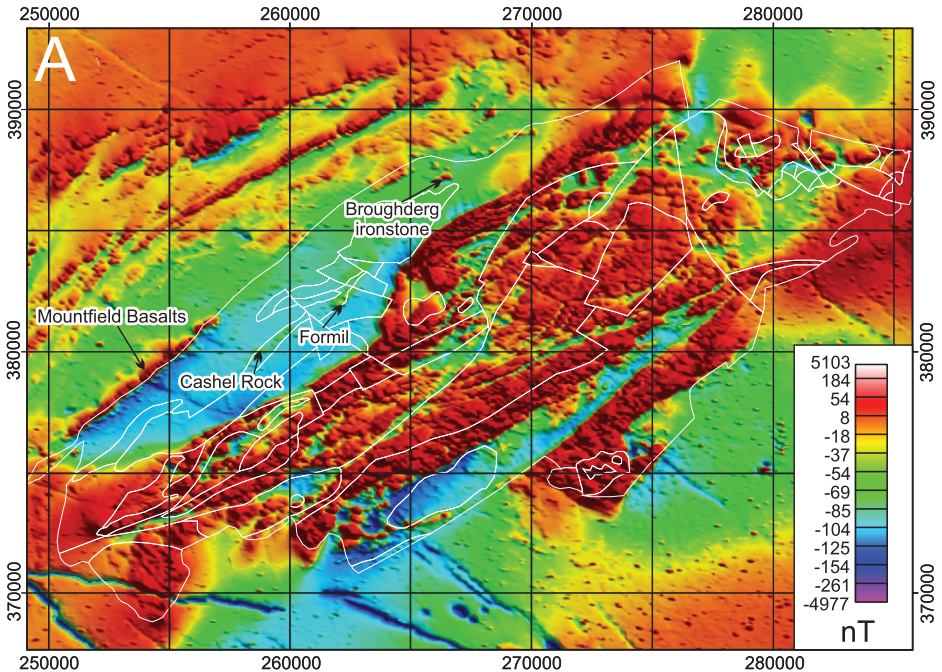

Figure 12.3. (A) Tellus TMIRTP map with previous GSNI 1:250,000 geological linework of the Tyrone Igneous Complex shown in white. (B) Tellus Low Frequency EM map with GSNI linework as in (C). (C) GSNI 1:250,000 geological map over the Tyrone Igneous Complex. Red boxes highlight the extent of Figs 12.2 and 12.4.
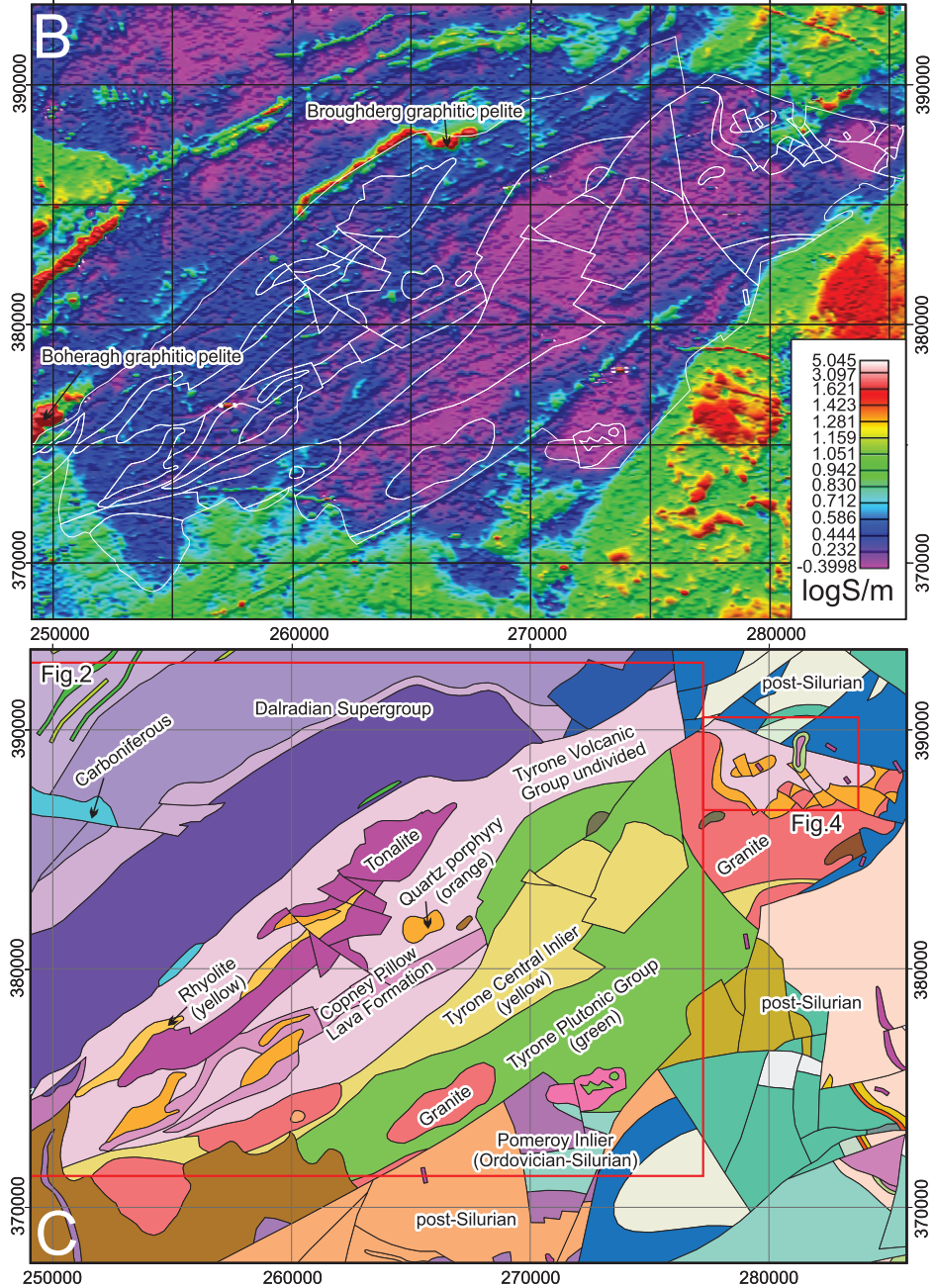
were dated by high-resolution isotope dilution thermal ionisation mass spectrometry $\mathrm{U}-\mathrm{Pb}$ zircon geochronology at the NERC Isotope Geosciences Laboratory (see Cooper et al., 2008 and subsequent publications).

Historic data from ground magnetic, induced polarisation, very low frequency electromagnetic (EM) resistivity (VLF/EM-R) geophysical surveys, deep overburden geochemistry and prospecting were compiled by Aurum Exploration Services. Tellus airborne EM anomalies were verified on the ground as cultural, bedrock or unexplained. Following the main phase of research, a prospecting campaign was implemented in 2011 throughout the entire Tyrone Volcanic Group by Dalradian Resources. During a second prospecting campaign, geophysical and geochemical anomalies of the Tellus and historic data sets were targeted around Crosh-Racolpa. Five diamond drill holes were also drilled in 2011 and early 2012 at Broughderg, Tullybrick and Cashel Rock (Fig. 12.2).

\section{Geology of the Tyrone Igneous Complex}

Interpretation of the Tellus geophysical data showed that the unexposed geology was much more complex than previously thought. Tellus geophysical imagery has revealed the structure of the Tyrone Igneous Complex in unprecedented detail (Fig. 12.3a, 12.3b), enhancing previous GSNI mapping (Fig. 12.3c). As a result, the evolution of the Tyrone Igneous Complex and its relationship to the Caledonian orogeny are now well understood (e.g. Cooper et al., 2011). The Tyrone Igneous Complex is broadly divisible into: (1) a structurally dissected c.484-479 Ma slice of subduction-affinity oceanic crust (Tyrone Plutonic Group); (2) the remnants of a c.475-469 Ma volcanic arc (Tyrone Volcanic Group); and (3) a late $c .470-464 \mathrm{Ma}$ suite of arc-related intrusive rocks. Several new formations have been identified and mapped in the Tyrone Volcanic Group (Figs 12.2, 12.4).

Of particular relevance to mineral exploration is the clear link now established between the Tyrone Igneous Complex and the Buchans-Robert's Arm arc system of Newfoundland (Hollis et al., 2012, 2013a), where historic mining at Buchans produced 16.2 Mt of ore at $14.51 \% \mathrm{Zn}, 7.56 \% \mathrm{~Pb}, 1.33 \% \mathrm{Cu}, 126 \mathrm{~g} / \mathrm{t}$ silver $(\mathrm{Ag})$ and $1.37 \mathrm{~g} / \mathrm{t}$ gold ( $\mathrm{Au}$ ) (Piercey, 2007). Several episodes of extension and high-temperature heat flow have been identified in the Tyrone Volcanic Group. VMS prospective stratigraphic horizons are associated with rift-related basalts, 'fertile' felsic rocks, ironstones (i.e. silica- and iron-rich rocks associated with hydrothermal activity; Fig. 12.5a), locally intense hydrothermal alteration (Fig. 12.5b), geophysical anomalies and base metal occurrences (Hollis et al., 2014).

Typical whole-rock geochemical variations associated with VMS deposits, due to the hydrothermal alteration of the host stratigraphy, are shown in Fig. 12.5b. Large gains in magnesium $(\mathrm{Mg})$, iron $(\mathrm{Fe})$ and sulphur $(\mathrm{S})$ occur in chloritised and mineralised footwall rocks under VMS deposits, associated with the movement of hydrothermal fluids through synvolcanic faults $\left(>250^{\circ} \mathrm{C}\right)$. Intensely chlorite-altered volcanic rocks have been identified in diamond drillcore from Cashel Rock, underlying zones of minor base metal mineralisation. Broader zones of quartz-sericite-(pyrite) alteration are associated with lower 


\section{Hollis et al.}

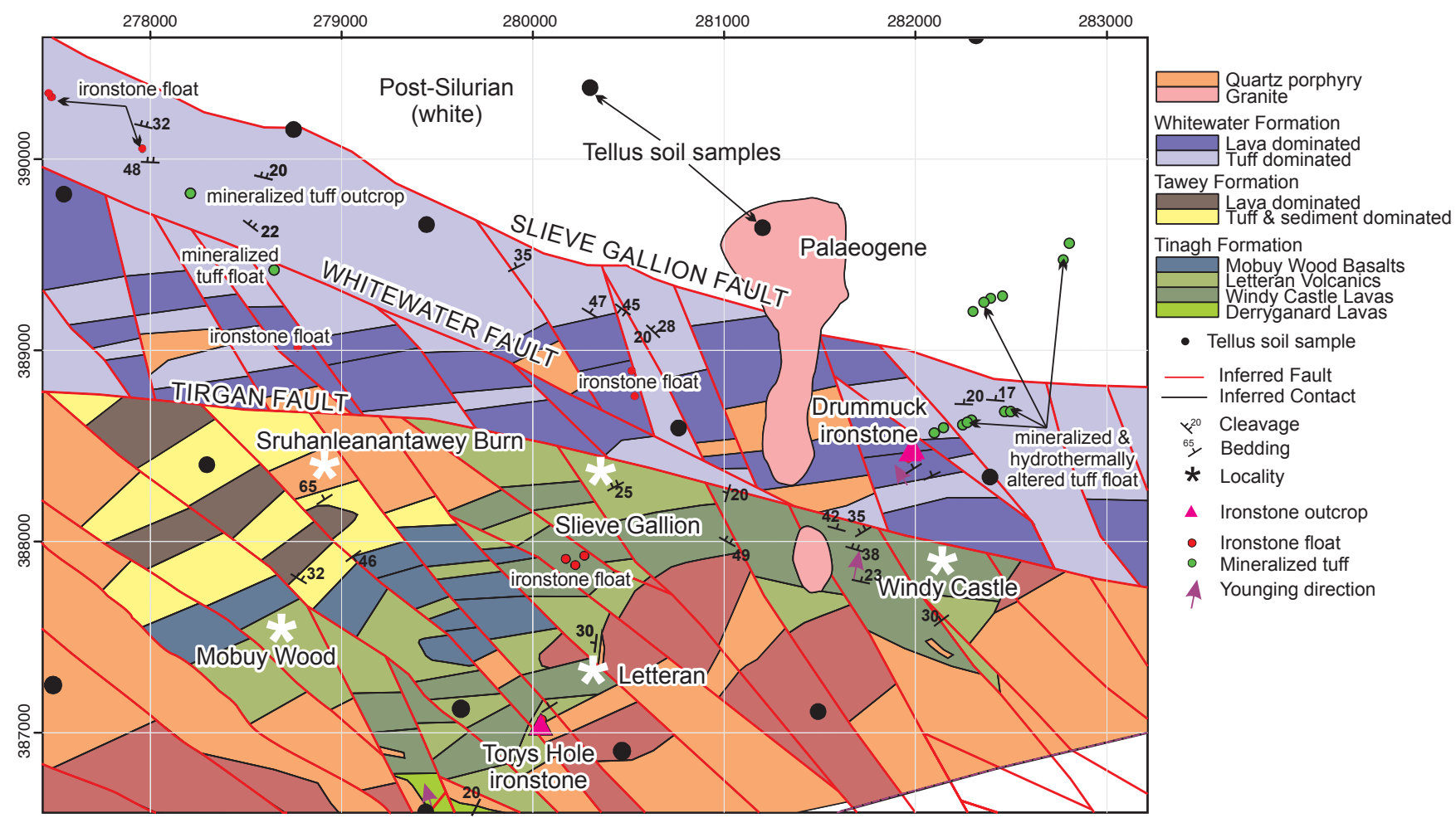

temperature, distal hydrothermal alteration surrounding VMS deposits. Similar alteration has been recognised at Tullybrick, Cashel Burn, Cashel Rock, Crosh, Racolpa and Formil (see Hollis et al., 2014; Fig. 12.2). In terms of geophysical responses, massive sulfides often Figure 12.4. Geological map of the Slieve Gallion Inlier (after Hollis et al., 2013b). have an EM response (although this can be masked by the presence of black shales in the stratigraphy). Magnetic highs may be associated with individual rock units in the host stratigraphy (e.g. ironstones), and massive sulfides or stringer mineralisation if pyrrhotite or magnetite are present. Demagnetised zones can occur in basaltic footwall rocks due to hydrothermal alteration.

\section{TARgETING MINERALISATION USING TELLUS DATA}

Extensive hydrothermal alteration across the Tyrone Igneous Complex has recently been detailed in Hollis et al. (2014). Here we highlight previously undescribed geochemical and geophysical anomalies identified from Tellus and historic data sets, building on previous work by Gunn et al. (2008) conducted for Metallum Resources. We focus on areas that are interpreted to have the greatest potential to host economic VMS mineralisation, and contain either outcropping mineralisation or abundant high-grade float. 


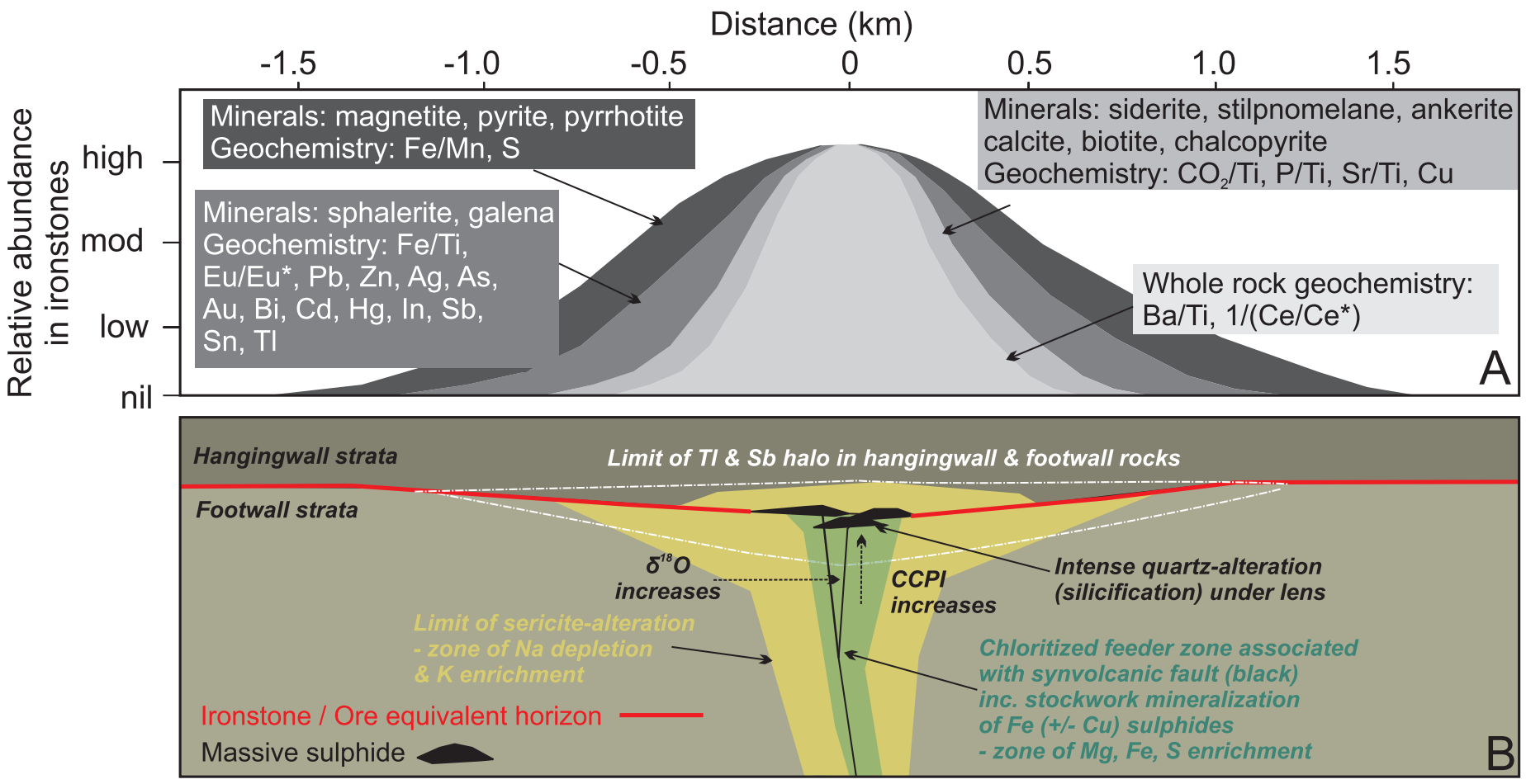

Figure 12.5. (A) Schematic diagram showing the lateral extent of mineral and bulk geochemical halos that surround VMS deposits in ironstones/iron formations of the Bathurst Mining Camp, Canada (after Peter and Goodfellow, 1996). Samples from Drummuck contain high $\mathrm{Ba} / \mathrm{Zr}, \mathrm{Fe} / \mathrm{Ti}, \mathrm{Sb}$ and $\mathrm{Eu} /$ $\mathrm{Eu}^{*}$ and are considered to be VMS-proximal (discussed in Hollis et al., 2015). (B) Typical whole rock geochemical variations surrounding VMS deposits due to the hydrothermal alteration of the host stratigraphy.

\section{Slieve Gallion}

Little exploration for VMS mineralisation has been undertaken in the $c .475-474 \mathrm{Ma}$ volcanic rocks exposed at Slieve Gallion (Fig. 12.4). Recent work has identified geochemically identical rift-related basalts to those in the main exposures of the Tyrone Volcanic Group to the south-west (Hollis et al., 2013b). At least two ironstones crop out in the area (Fig. 12.4), one of which (at Drummuck) displays geochemical characteristics typical of deposits proximal to VMS systems (Fig. 12.5a). These characteristics include high iron/ titanium $(\mathrm{Fe} / \mathrm{Ti})$ ratios, elevated concentrations of barium $(\mathrm{Ba})$ and antimony $(\mathrm{Sb})$, and higher concentrations of europium $(\mathrm{Eu})$ with respect to the other rare earth elements (i.e. $\mathrm{Eu} / \mathrm{Eu}^{*}>$ 1: Fig. 12.5a) (see Hollis et al., 2015). Historic prospecting results from downstream of the Drummuck ironstone include barite cobbles and silicified tuffs with $0.23 \%$ $\mathrm{Zn}, 0.11 \% \mathrm{~Pb}$ and $0.5 \mathrm{ppm} \mathrm{Ag}$ (Fig. 12.6a). Abundant mineralised float also occurs -900 $\mathrm{m}$ to the north-east in an adjacent stream section (Fig. 12.6b). The Drummuck ironstone (Fig. 12.7a) corresponds to a Tellus magnetic (TMI-tilt and 1VD) anomaly which extends for $-400 \mathrm{~m}$ along strike before it is cut off at each end by north-west to south-east trending faults. This area represents a key target for exploration, with Tellus soil and stream sediment $\mathrm{Sb}$ anomalies immediately downstream (Fig. 12.7b), and areas of high Au in stream sediments $1.5 \mathrm{~km}$ to the east (Fig. 12.7a). Zinc and Pb stream sediment anomalies (to 269 and $59 \mathrm{ppm}$ respectively) occur $-1.5 \mathrm{~km}$ to the north-east associated with ironstone float 


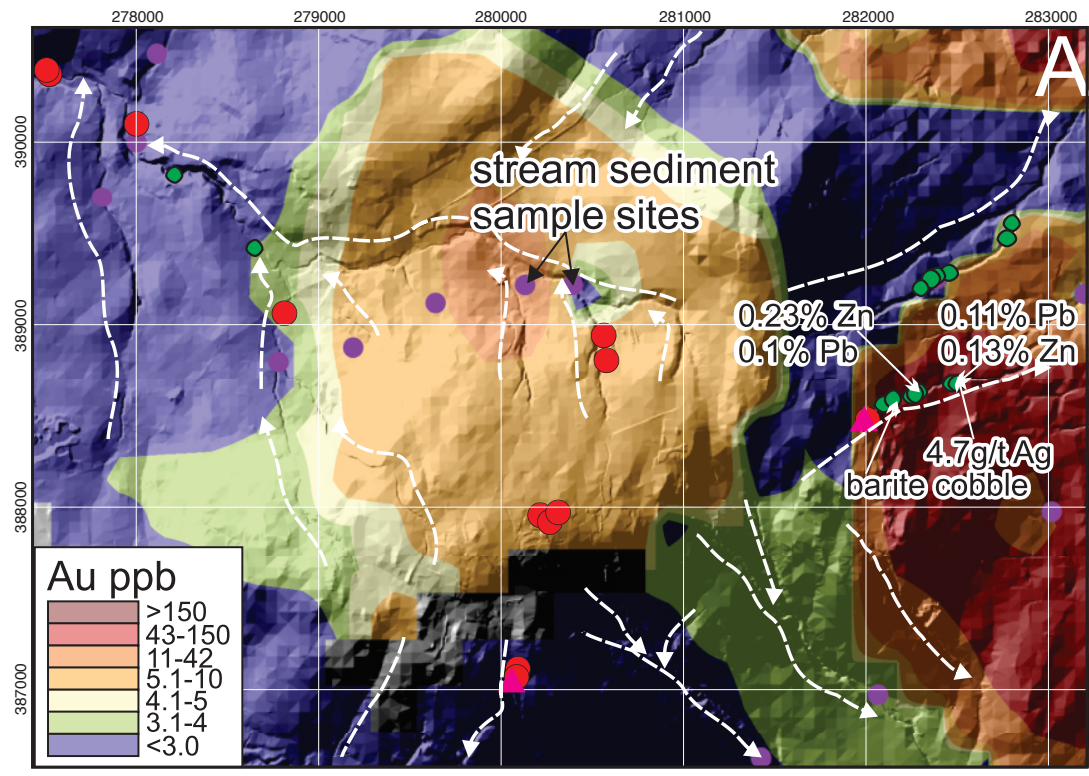

- Tellus soil sample

- Tellus stream sediment sample Inferred Fault - Inferred Contact

$\mathrm{x}^{20}$ Cleavage

65 Bedding

* Locality

- Ironstone outcrop

- Ironstone float

- Mineralized tuff

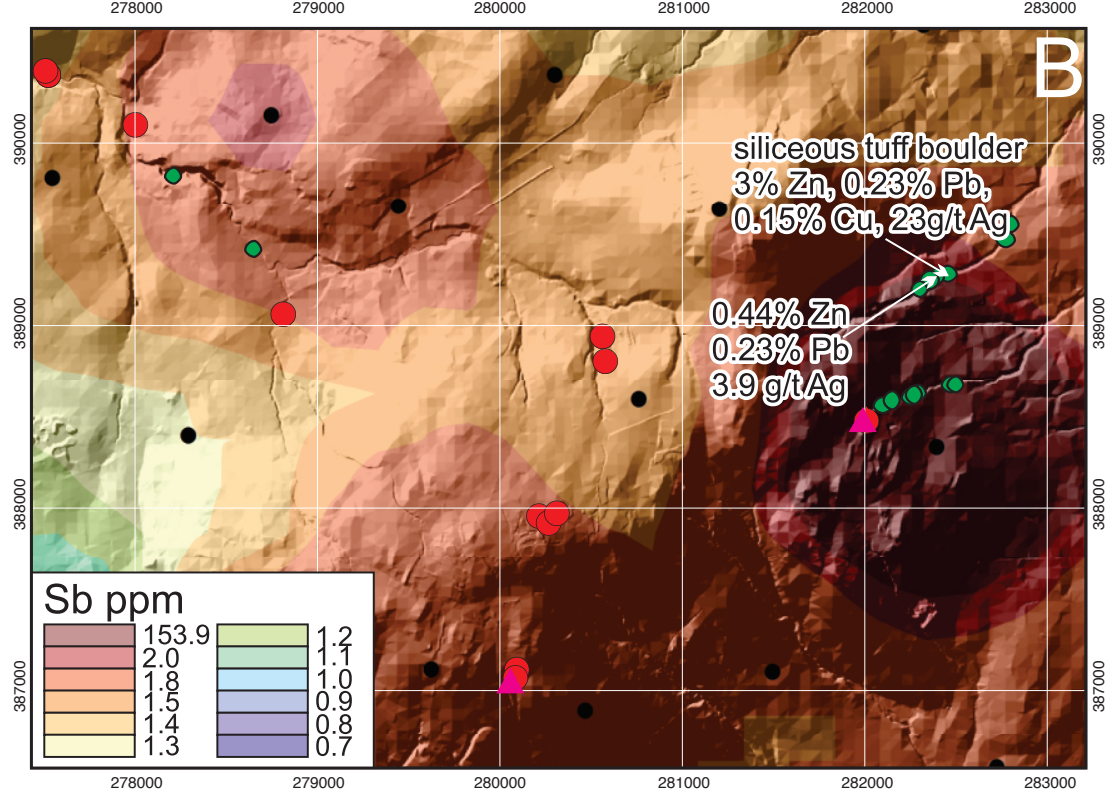

at a similar stratigraphic level (Fig. 12.4). High arsenic (As), $\mathrm{Zn}, \mathrm{Pb}$ and $\mathrm{Cu}$ in stream waters are restricted to the Whitewater River area, where intensely silica-sericite-pyrite(fuchsite) altered tuff and ironstone float have been identified (Fig. 12.4). Gold has been panned from both Whitewater River and Iniscarn Water (Drummuck area).

\section{Greencastle Formation}

In the c. 473-470 Ma Greencastle Formation of the upper Tyrone Volcanic Group, rhyolites prospective for VMS mineralisation occur at Formil, Cashel Rock and Racolpa
Figure 12.6. (A) Tellus stream sediment gold $(\mathrm{Au})$ map over a digital terrain model of the Slieve Gallion Inlier. (B) Tellus soil antimony (Sb) map over the same digital terrain model. Areas of ironstone float and mineralised tuff are also highlighted. This figure covers the same area as shown in Fig. 12.4. White arrows show flow directions for major rivers and streams. 


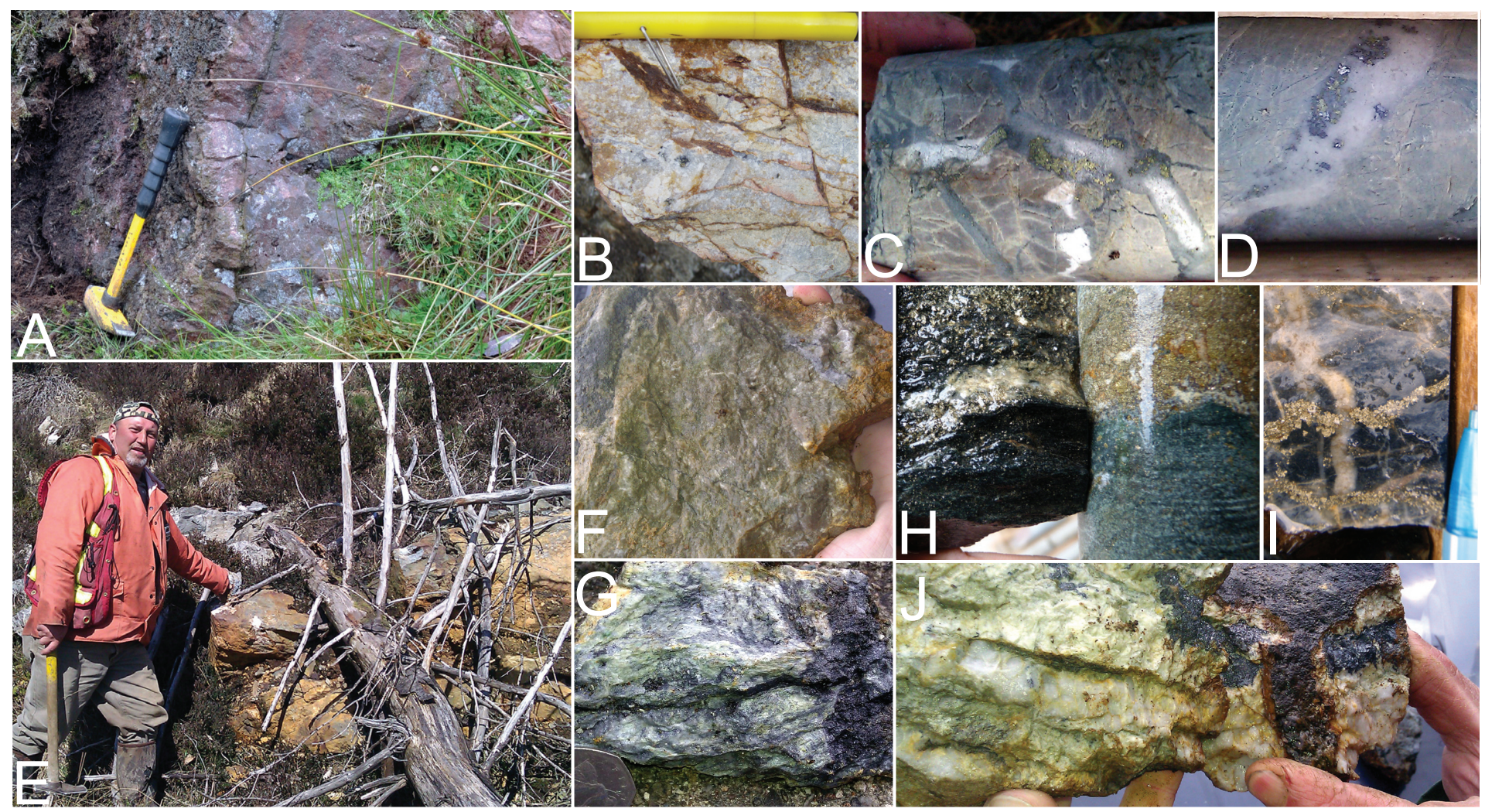

Figure 12.7. Representative mineralised volcanic rocks from the Tyrone Volcanic Group. (A) Ironstone from Drummuck (Slieve Gallion) that displays VMS-proximal geochemical characteristics

(see Fig. 12.5a) and is associated with mineralised float downstream. (B) Silicified rhyolite from Cashel Rock (to

$112 \mathrm{~g} / \mathrm{t} \mathrm{Au}$ in grab samples) (C-D) Silicified rhyolite with visible chalcopyrite and galena (drillhole 11-CR-01). (E)

Massive pyrite at Formil. (F) Silicified and sericite-altered rhyolite from Racolpa. (G) Mineralised tuff outcrop, Cashel Burn. (H) Mineralised pyrite-bearing chloritic tuff, Cashel Bridge (drillhole 106-200). (I) Mineralised chert/ironstone at Broughderg (drillhole 91-1). (J) Silicified and sericite-altered rhyolite, Crosh base metal occurrence.
(Fig. 2). Mineralised tuffs also occur at Aghascrebagh (4\% Pb, 1.22\% $\mathrm{Zn}$ and $5.94 \mathrm{~g} / \mathrm{t}$ $\mathrm{Au})$, Greencastle (10\% Zn, 2.83\% Pb and $1.23 \% \mathrm{Cu})$, Cashel Burn, and Tullybrick (0.92 $\mathrm{g} / \mathrm{t} \mathrm{Au}$ ) (Fig. 2).

The Cashel Rock VMS occurrence has been known for some time (Clifford et al., 1992) and has received the most attention of all localities. A Tellus TMI-tilt magnetic anomaly extends for $-2.6 \mathrm{~km}$, with the southernmost TMI-RTP magnetic 'bullseye' (Fig. 12.3a) located at the site of drilling and outcropping mineralisation (Fig. 7b). A 1-4 m wide zone of Au mineralisation associated with silica-flooding (e.g. $3.63 \mathrm{~m}$ at $30.51 \mathrm{~g} / \mathrm{t} \mathrm{Au}$, including $1.23 \mathrm{~m}$ at $1.14 \% \mathrm{Cu}$ and $1.85 \% \mathrm{~Pb}$ ) extends for at least $200 \mathrm{~m}$ down dip. On the most southerly drill section this is underlain by a chloritic stockwork (see Fig. 12.5b) and is associated with minor base metal mineralisation (Fig. 12.7c, 12.7d). A Tellus EM conductivity anomaly further south remains unexplained.

At Formil, a $\sim 800 \mathrm{~m}$ long Tellus magnetic (TMI-RTP and TIM-tilt) anomaly (Fig. 12.3a) is coincident with outcropping massive pyrite with disseminated magnetite (Fig. 12.7e). Prospecting and mapping in 2011-12 identified abundant secondary $\mathrm{Cu}$ mineralisation (malachite) in new rock exposures to the west and north associated with high concentrations of $\mathrm{Cu}(226 \mathrm{ppm}), \mathrm{Zn}(330 \mathrm{ppm})$ and $\mathrm{Pb}$ (to $245 \mathrm{ppm}$ ) in historic deep overburden geochemistry. Historic drilling around Formil by Riofinex during the 1970s intersected only weak $\mathrm{Cu}$ mineralisation. Induced polarisation anomalies targeted by Ennex 
during the 1980s were largely barren. A series of Tellus EM anomalies in the vicinity are unexplained. No drilling has occurred in the vicinity of the massive pyrite, and mineralisation at Formil remains poorly understood.

At Racolpa, base and precious metal mineralisation was recognised during the 2011 prospecting campaign, with $2.19 \mathrm{~g} / \mathrm{t}$ Au in outcrop (Fig. 12.7f). Mineralised rhyolite was also sampled to the north near Faccary Bridge $(2.69 \% \mathrm{Cu}+\mathrm{Pb}+\mathrm{Zn}$ and $0.34 \mathrm{~g} / \mathrm{t} \mathrm{Au}$ in float), and subcrops further east at Mulnafye $(1.33 \% \mathrm{Cu}+\mathrm{Pb}+\mathrm{Zn}$ and $0.3 \mathrm{~g} / \mathrm{t} \mathrm{Au})$. Several small $(-300 \mathrm{~m}$ long) unexplained Tellus magnetic anomalies occur in the vicinity of the Racolpa rhyolite, though none are coincident with outcropping mineralisation. At Mulnafye, white quartz float (to $71.5 \mathrm{~g} / \mathrm{t} \mathrm{Au}$ ) with visible gold, chalcopyrite and malachite staining brecciates tonalite near its contact with the Racolpa rhyolite.

Outcropping VMS mineralisation at Cashel Burn $(1.63 \mathrm{~g} / \mathrm{t} \mathrm{Au}$ and $4.3 \% \mathrm{Cu}+\mathrm{Pb}+\mathrm{Zn}$; Fig. $12.7 \mathrm{~g}$ ) remains a high priority target for drilling. However, all Tellus geophysical anomalies in the vicinity of mineralisation are interpreted as either cultural or related to glacial deposits.

\section{Broughderg Formation}

VMS prospective and mineralised volcanic rocks in the $c .469$ Ma Broughderg Formation occur at Cashel Bridge, Crosh and Broughderg (Fig. 12.2). Historic drilling at Cashel Bridge by Ennex intercepted narrow zones of base metal mineralisation (e.g. $40 \mathrm{~cm}$ at $3.36 \% \mathrm{~Pb}+\mathrm{Zn}$; Fig. $12.7 \mathrm{~h}$ ), and there are no clear Tellus geophysical anomalies to guide further drilling.

At Broughderg, a large Tellus magnetic (TMI-RTP) 'bullseye' is associated with an ironstone unit (Fig. 12.3a), where historic shallow drilling by Ennex intercepted minor Au mineralisation $(0.62 \mathrm{~m}$ at $1.68 \mathrm{~g} / \mathrm{t}$ Au; Fig. 12.7i). Trace-element geochemistry, such as elevated $\mathrm{Ag}$, As, $\mathrm{Au}$, cadmium (Cd), Cu, molybdenum (Mo), $\mathrm{Pb}$, thallium ( $\mathrm{Tl}$ ) and $\mathrm{Zn}$, indicates this ironstone may be related to VMS mineralisation (Hollis et al., 2015; Fig. 12.5a). Drilling of this bullseye anomaly in 2011 (down dip of historic exploration) intercepted background levels of Au only. Any potential VMS-related EM anomalies are masked by the thick sequences of overlying graphitic pelite (Fig. 12.3b). However, the potential for VMS mineralisation along strike remains.

At Crosh, outcropping base-metal mineralisation (2.99\% $\mathrm{Cu}+\mathrm{Pb}+\mathrm{Zn}$; Fig. 12.7j) is associated with one of two $500 \mathrm{~m}$ long Tellus EM anomalies and remains untested by drilling. Anomalous $\mathrm{Zn}(134 \mathrm{ppm})$ in Tellus soil samples occurs to the south. Targeted prospecting of historic EM and Tellus geophysical anomalies in the vicinity of the Crosh base metal occurrence in 2011-12 identified new Au occurrences associated with silicified volcanic rocks and resistivity highs. 


\section{Carrickmore}

The rocks of the $c .484-479 \mathrm{Ma}$ Tyrone Plutonic Group have only limited potential as targets for $\mathrm{Cu}$-rich VMS mineralisation. Most parts of the preserved stratigraphy were not conducive to VMS formation (Hollis et al., 2014). Historic Cu mineralisation has been noted in the sheeted dykes around Carrickmore Quarry (Fig. 12.2), broadly coincident with Tellus soil $\mathrm{Cu}(545 \mathrm{ppm})$ and $\mathrm{Zn}(167 \mathrm{ppm})$ anomalies. $\mathrm{Cu}-\mathrm{Au}$ mineralisation has also been recorded from malachite-stained quartz float among diorite outcrop to the north-east (e.g. $0.7 \mathrm{~g} / \mathrm{t} \mathrm{Au}, 0.74 \% \mathrm{Cu}$ ).

\section{Conclusions}

The Tellus survey has revealed the structure of the Tyrone Igneous Complex in unprecedented detail. With high-resolution geophysics aiding bedrock mapping, isolated outcrops were put into a detailed stratigraphic framework for the first time. This allowed detailed geochemistry and U-Pb zircon geochronology to be put into context, permitting robust correlations to be made across the Caledonian-Appalachian orogen. Furthermore, key stratigraphic horizons were identified that are prospective for VMS mineralisation. Targeting of Tellus geochemical and geophysical anomalies along these horizons has identified several new mineralised outcrops and zones ripe for further exploration.

\section{ACKNowledgements}

We thank a number of project collaborators to whom we are greatly indebted, particularly Daniel Condon, Quentin Crowley and Stephen Noble for their meticulous U-Pb zircon work. Sandy Archibald, Robin Taggart, Hilary Clarke and Dalradian Resources personnel (particularly Gavin Berkenheger, Raymond Keenan, Martin Moloney and Orla McKenna) are thanked for many thoughtful discussions. Prospectors Dan Moss, Allan Keats and Calvin Keats discovered several new mineralised outcrops in the Tyrone Volcanic Group. PhD research was funded by the British Geological Survey (BGS University Funding Initiative), University of Southampton, Dalradian Resources, GSNI, Natural History Museum, London, and Metallum Resources. U-Pb zircon geochronology was funded through a combination of Northern Ireland Department of Enterprise, Trade and Investment and Environment Agency funding. Constructive comments from Editor Mike Young and reviewers Gus Gunn and Charlie Moon greatly improved this manuscript. MRC publishes with the permission of the Executive Director of the British Geological Survey (NERC).

\section{REFERENCES}

Clifford, J.A., Earls, G., Meldrum, A.H. and Moore, N., 1992 'Gold in the Sperrin Mountains, Northern Ireland: an exploration case history’ in A.A. Bowden, G. Earls, P.G. O’Connor and J.F Pyne (eds), The Irish Minerals Industry 1980-1990, 77-87. Dublin. Irish Association for Economic Geology. 
Cooper, M.R., Crowley, Q.G. and Rushton, A.W.A., 2008 'New age constraints for the Ordovician Tyrone Volcanic Group, Northern Ireland', Journal of the Geological Society, 165, 333-9.

Cooper, M.R., Crowley, Q.G., Hollis, S.P., Noble, S.R., Roberts, S., Chew, D., Earls, G., Herrington, R. and Merriman, R.J., 2011 'Age constraints and geochemistry of the Ordovician Tyrone Igneous Complex, Northern Ireland: implications for the Grampian orogeny', Journal of the Geological Society, 168, 837-50.

Galley, A.G., Hannington, M.D. and Jonasson, I.R., 2007 'Volcanogenic massive sulphide deposits', in W.D. Goodfellow (ed.), Mineral Deposits of Canada: A Synthesis of Major Deposit-Types, District Metallogeny, the Evolution of Geological Provinces, and Exploration Methods. Ottawa. Geological Association of Canada, Mineral Deposits Division, Special Publication, 5, 141-61.

Gunn, A.G., Lusty, P.A.J., McDonnell, P.M. and Chacksfield, B.C., 2008, A Preliminary Assessment of the Mineral Potential of Selected Parts of Northern Ireland. British Geological Survey Commissioned Report, CR/07/149. Keyworth.

Hollis, S.P., 2013 Evolution and mineralization of volcanic arc sequences: Tyrone Igneous Complex, Northern Ireland. Unpublished PhD thesis, University of Southampton.

Hollis, S.P., Roberts, S., Cooper, M.R., Earls, G., Herrington, R.J., Condon, D.J., Cooper, M.J., Archibald, S.M. and Piercey, S.J., 2012 'Episodic-arc ophiolite emplacement and the growth of continental margins: late accretion in the Northern Irish sector of the Grampian-Taconic orogeny', GSA Bulletin, 124, 1702-23.

Hollis S.P., Cooper M.R., Roberts S., Earls G., Herrington R.J., Condon D.J. and Daly, J.S., 2013a 'Late obduction of the Tyrone ophiolite, Northern Ireland, during the Grampian-Taconic orogeny: a correlative of the Annieopsquotch ophiolite of Newfoundland?', Journal of the Geological Society, 170, 861-76.

Hollis, S.P., Cooper M.R., Roberts, S., Herrington, R.J., Earls, G. and Condon, D.J., 2013b 'Stratigraphic, geochemical and U-Pb zircon age constraints from Slieve Gallion, Northern Ireland: a correlation of the Irish Caledonian arcs', Journal of the Geological Society, 170, 737-52.

Hollis, S.P., Roberts, S., Earls, G., Herrington, R., Cooper, M.R., Piercey S.J., Archibald, S.M. and Moloney, M., 2014 'Petrochemistry and hydrothermal alteration within the Tyrone Igneous Complex, Northern Ireland: implications for VMS mineralization in the peri-Laurentian British and Irish Caledonides', Mineralium Deposita, 49, 575-93.

Hollis, S.P., Cooper, M.R., Herrington, R.J., Roberts, S., Earls, G., Verbeeten, A., Piercey, S.J. and Archibald, S.M., 2015 'Distribution, mineralogy and geochemistry of silica-iron exhalites and related rocks from the Tyrone Igneous Complex: implications for VMS mineralization in Northern Ireland', Journal of Geochemical Exploration, 159, 148-68. doi: 10.1016/j.gexplo.2015.09.001.

Peter, J.M. and Goodfellow, W.D, 1996 'Mineralogy, bulk and rare earth element geochemistry of massive sulphide-associated hydrothermal sediments of the Brunswick Horizon, Bathurst Mining Camp, New Brunswick', Canadian Journal of Earth Sciences, 33, 252-83.

Piercey, S.J., 2007 'Volcanogenic massive sulphide (VMS) deposits of the Newfoundland Appalachians: an overview of their setting, classification, grade-tonnage data, and unresolved questions', in C.G.P. Pereira and D.G. Walsh (eds), Current Research Report 07-01, 169-78. St John's, Canada. Newfoundland Department of Natural Resources, Geological Survey. 
Unearthed: impacts of the Tellus surveys of the north of Ireland

First published in 2016 by the

Royal Irish Academy

19 Dawson Street

Dublin 2

www.ria.ie

Copyright (C) 2016 Royal Irish Academy

ISBN: 978-1-908996-88-6

The articles in this book are open access and distributed under the terms of the Creative Commons Attribution 4.0 licence, which permits unrestricted use, distribution and reproduction in any medium, provided the original authors and source are credited. To view a copy of this licence, visit https://creativecommons.org/licenses/by/4.0/

Except where noted:

Geological mapping for Northern Ireland / Tellus data are provided by the Geological Survey of Northern Ireland.

Geological mapping for Ireland / Tellus Border data are provided by the Geological Survey of Ireland.

Topographic mapping for Northern Ireland is derived from Land and Propery Services Open Data and contains public sector information licensed under the Open Government Licence v3.0. (http://www.nationalarchives.gov.uk/doc/open-governmentlicence/version/3/).

Topographic mapping for Ireland is derived from Ordnance Survey of Ireland Open Data (https://creativecommons.org/licenses/by/4.0/legalcode).

While every effort has been made to contact and obtain permission from holders of copyright, if any involuntary infringement of copyright has occurred, sincere apologies are offered, and the owner of such copyright is requested to contact the publisher.

British Library Cataloguing-in-Publication Data. A catalogue record is available from the British Library.

Design: Alex Donald, Geological Survey of Northern Ireland.

Index: Brendan O'Brien.

Printed in Poland by L\&C Printing Group. 


\section{Table of Contents:}

\section{Prelim}

DOI: https://doi.org/10.7486/DRI.b851k323d

\section{Chapter 1}

The Tellus geosciences surveys of the north of Ireland: context, delivery and impacts

DOI: https://doi.org/10.7486/DRI.st74s528d

\section{Chapter 2}

The Tellus airborne geophysical surveys and results DOI: https://doi.org/10.7486/DRI.t148tx96z

\section{Chapter 3}

The Tellus geochemical surveys, results and applications

DOI: https://doi.org/10.7486/DRI.t722wq645

\section{Chapter 4}

Stakeholder engagement for regional geoscientific surveying: the Tellus Border communications campaign

DOI: https://doi.org/10.7486/DRI.w089fr763

\section{Chapter 5}

Mineral resources and Tellus: the essential balance DOI: https://doi.org/10.7486/DRI.wd37kb12s

\section{Chapter 6}

Gold exploration in the north of Ireland: new targets from the Tellus Projects

DOI: https://doi.org/10.7486/DRI.wh24m696v

\section{Chapter 7}

Using soil geochemistry to investigate gold and base metal distribution and dispersal in the glaciated north of Ireland

DOI: https://doi.org/10.7486/DRI.wm11n3806

\section{Chapter 8}

Critical metals for hightechnology applications: mineral exploration potential in the north of Ireland DOI: https://doi.org/10.7486/DRI.wp98p0649

\section{Chapter 9}

A natural laboratory for critical metals investigations in the Mourne Mountains granites

DOI: https://doi.org/10.7486/DRI.cc08ww45f

\section{Chapter 10}

Geothermal potential of granitic rocks of the Mourne Mountains

DOI: https://doi.org/10.7486/DRI.ff36jm09f

\section{Chapter 11}

Shape and intrusion history of the Late Caledonian

Newry Igneous Complex, Northern Ireland

DOI: https://doi.org/10.7486/DRI.2v248822m

\section{Chapter 12}

Using Tellus data to enhance targeting of volcanogenic massive sulphide mineralisation in the Tyrone Igneous Complex

DOI: https://doi.org/10.7486/DRI.5x226w262

\section{Chapter 13}

The geological significance of electrical conductivity anomalies of the Ordovician- Silurian Moffat Shale Group, Northern Ireland

DOI: https://doi.org/10.7486/DRI.6m31f4149

\section{Chapter 14}

Faults, intrusions and flood basalts: the Cenozoic structure of the north of Ireland

DOI: https://doi.org/10.7486/DRI.90205h306

\section{Chapter 15}

Information for agriculture from regional geochemical surveys: the example of soil $\mathrm{pH}$ in the Tellus and Tellus Border data

DOI: https://doi.org/10.7486/DRI.dv14c8060

\section{Chapter 16}

An ecohydrological investigation of wetlands in the border counties of Ireland: a framework for a holistic understanding of wetland systems DOI: https://doi.org/10.7486/DRI.hd775d90j 
Chapter 17

Assessing nutrient enrichment risk to groundwaterdependent ecosystems in the border counties of Ireland DOI: https://doi.org/10.7486/DRI.k356pk18j

\section{Chapter 18}

Mapping the terrestrial gamma radiation dose

DOI: https://doi.org/10.7486/DRI.k930rb86z

\section{Chapter 19}

Soils and their radiometric characteristics

DOI: https://doi.org/10.7486/DRI.mp495t62g

\section{Chapter 20}

Modelling in-house radon potential using Tellus data and geology to supplement inhouse radon measurements

DOI: https://doi.org/10.7486/DRI.ns06hm86z

\section{Chapter 21}

Determining geochemical threshold values from the Tellus data sets: the examples of zinc and iodine| DOI: https://doi.org/10.7486/DRI.r2087418g

\section{Chapter 22}

Identification of the geochemical signatures of diffuse pollution in the Tellus Border soil data set, using source apportionment

DOI: https://doi.org/10.7486/DRI.wh24m698d

\section{Chapter 23}

Stream sediment background concentrations in mineralised catchments in Northern Ireland: assessment of 'pressures' on water bodies in fulfilment of Water Framework Directive objectives DOI: https://doi.org/10.7486/DRI.x633tf86g

\section{Chapter 24}

Mapping metallic contamination of soils in the Lower Foyle catchment

DOI: https://doi.org/10.7486/DRI.9k42bv355

\section{Chapter 25}

Refining the human health risk assessment process in Northern Ireland through the use of oral bioaccessibility data

DOI: https://doi.org/10.7486/DRI.9p29cr199

\section{Chapter 26}

Combining environmental and medical data sets to explore potential associations between environmental factors and health: policy implications for human health risk assessments

DOI: https://doi.org/10.7486/DRI.9s16dn03n

\section{Chapter 27}

Mapping a waste disposal site using Tellus airborne geophysical data

DOI: https://doi.org/10.7486/DRI.9w03fh87q

\section{Chapter 28}

The use of aero-magnetics to enhance a numerical groundwater model of the Lagan Valley aquifer, Northern Ireland

DOI: https://doi.org/10.7486/DRI.9z90gd711

\section{Chapter 29}

Carbon sequestration in the soils of Northern Ireland: potential based on mineralogical controls DOI: https://doi.org/10.7486/DRI.b277h9556

\section{Chapter 30}

Spatial distribution of soil geochemistry in geoforensics DOI: https://doi.org/10.7486/DRI.b564j6392

\section{End matter}

DOI: https://doi.org/10.7486/DRI.bc38m007j 